\title{
18 RECLAIMING THROUGH RENAMING: THE REINSTATEMENT OF KAURNA TOPONYMS IN ADELAIDE AND THE ADELAIDE PLAINS
}

\author{
Rob Amery and Georgina Yambo Williams
}

Some placenames on the Adelaide Plains, such as Yankalilla, Myponga, Aldinga, Willunga and Waitpinga, have always been in use. ${ }^{1}$ These localities have always been known by their Indigenous names and only by their Indigenous names. Yankalilla, for instance, was in use by sealers based at Kangaroo Island before colonisation and also recorded by George Augustus Robinson on 2 June 1837 in an interview with Kalloongoo, a Kaurna woman who had been kidnapped from the district some years previous (see Amery 1996). The name appeared in Colonel Light's journals and was in frequent use before the establishment of a settlement in the district. However, while these names are used in the same vicinity of the original place, it is not clear whether any of these names now refer to the same place that they did 200 years ago. For instance, Myponga now refers to a town, a district, the Hundred ${ }^{2}$ of Myponga and a reservoir. The district of Myponga is probably not co-extensive with Maitpangga as known to Kaurna people in the early nineteenth century. Teichelmann and Schürmann (1840) indicate that it then referred to a plain. The remaining entities (the town, reservoir and Hundred) of course did not even exist in those days.

Even so, few South Australians know the meanings of these names and the meanings promoted by local councils and books on placenames are often highly suspect. In some cases (e.g. Yankalilla or Onkaparinga), the name is the key to understanding the landscape from a Kaurna perspective. So there is a need, not only to reinstate the names themselves, but to rehabilitate the understandings behind existing names.

George Gawler, South Australia's second governor (1838-1841), actively promoted the application of Aboriginal placenames where these were known:

\footnotetext{
1 Paper presented at the 'Placenames of Indigenous Origin in Australia: An Interdisciplinary Workshop', 31 October 1999, Department of Linguistics, Australian National University, Canberra.

2 'Hundred' means a major division of land, the purpose of which is to provide unique identities for properties in conjunction with the section numbers. The actual size varies from one to another (Bill Watt pers. comm.).
}

L. Hercus, F. Hodges and J. Simpson, eds, The Land is a Map: placenames of Indigenous origin in Australia, 255-276. Canberra: Pandanus Books in association with Pacific Linguistics, 2002. 
In regard to the minor features of the country to which the natives may have given names, the Governor would take the present opportunity of requesting the assistance of the colonists in discovering and carefully and precisely retaining these in all possible cases as most consistent with property and beauty of appellation.

All information on this subject should be communicated in precise terms to the Surveyor-General who will cause memoranda to be made of it and native names, when clearly proved to be correct, to be inserted in the public maps. (Government Gazette, 31 October 1839, cited in Cockburn 1990:xviii)

Not only did Gawler exhort the colonists to seek information relating to Indigenous placenames, but he also appears to be responsible for the reinstatement of at least one Kaurna name. T\&S (1840) give Pattawilya as the Kaurna name for Glenelg. Patawalonga, the name of the waterway that drains into the sea at Glenelg, is derived from Pattawilya $+-n g g a$. However, the plan prepared by Light, Finnis \& Co. in 1836 and approved by Governor Gawler shows the Patawalonga as the River Thames (Cockburn 1990:87). It appears that the English name was never officially adopted and the Indigenous name prevailed. Gawler was also responsible for the reinstatement of Onkaparinga in 1838. This watercourse appears as Field's River on Colonel Light's charts (Manning 1986:157).

There are possibly other examples earlier this century where Kaurna names may have been reinstated. The suburb of Taperoo in the Port Adelaide area was laid out in 1925 by Wilkinson Watkinson. Before that, the area was known as Silicate. According to Manning (1986:202), Taperoo 'is aboriginal for calm', though Kaurna tapurro 'possum skin drum' seems a more likely etymology. It is unclear whether Taperoo is a reinstated original Kaurna name, or even if it is Kaurna at all. Pooraka is another puzzling case. 'In 1916 the Yatala District Council discarded the name "Dry Creek" as applied to the old post office, in favour of Pooraka, a native word meaning "dry creek" (Cockburn 1908:56; 1990:63) while Praite and Tolley (1970:148) say it means 'dry waterhole', also found in Endacott (1955:48), a source which draws primarily on Victorian materials. The origins of Pooraka are obscure. It bears no resemblance to documented Kaurna words for 'dry' or 'creek'. Yet it was named at a time before the appearance of books promoting the use of Aboriginal words from anywhere and everywhere. Perhaps it was in fact the original name for the Dry Creek watercourse itself. However, Pooraka does appear in Ingamells (1955) and Reed (1967) with the same spelling, where it is identified as a New South Wales word meaning 'turpentine tree'.

There are certainly more recent examples where non-Aboriginal people or government agencies have applied or reinstated Kaurna names without reference to the Kaurna community. For instance, the Osmond Terrace Drug and Alcohol Rehabilitation Centre was renamed Warinilla in 1985 after the original homestead there (Robin Brandler, pers. comm., 7 November 1997). The name Warinilla was certainly in use in the mid-1920s or early 1930s when the property was sold by the Holden family and may well date back to the early years of the colony.

Warekila Lodge was named in about 1992-1993 after the original name for Happy Valley, where it is located. The name Warekila was obtained from Cooper (1962), in which it is said to mean 'place of changing winds' (Gwen, pers. comm., Warekila Lodge; Paul Springthorpe, November 1997). 


\title{
1 BELAIR NATIONAL PARK
}

There is just one locality in Kaurna country today where Kaurna names almost dominate the map. Even though all the main roads and several other features are named with English names and several words from other Aboriginal languages have been imported, the main natural features - the creeks and ridges within Belair National Park —- bear Kaurna names as follows:

$\begin{array}{ll}\text { Willa-willa Ridge } & \text { (cf. T\&S Willawilla 'Brownhill Creek') } \\ \text { Warri-Parri Ridge } & \text { (cf. T\&S Warriparri 'Sturt River') } \\ \text { Yulti-Wirra Ridge } & \text { (cf. T\&S yulti 'stringybark'; wirra 'forest; bush') } \\ \text { Perroomba Creek } & \text { (cf. T\&S purrumba 'flower, blossom'; Wyatt (1879) perroomba) } \\ \text { Kurru Creek } & \text { (cf. T\&S kurru 'grass tree') } \\ \text { Tilti Creek } & \text { (cf. T\&S tilti 'native cherry') } \\ \text { Minno Creek } & \text { (cf. T\&S minno 'wattle, wattle gum') } \\ \text { Tarnma Creek } & \text { (cf. T\&S tarnma 'honeysuckle') } \\ \text { Tarpurro Creek } & \text { (cf. T\&S tapurro 'possum skin, drum') } \\ \text { Karka Creek } & \text { (cf. T\&S karka 'sunset, dusk'; karko 'sheoak'; Wyatt (1879) karkoo } \\ \text { 'sheoak') } \\ \text { Workanda Creek } & \text { (cf. T\&S workanda 'cataract, cascade') }\end{array}$

On the face of it, it would seem that the names may be original retentions. The country down from Willa-willa Ridge is in fact the head reaches of Brownhill Creek, known to the Kaurna as Willawilla (T\&S) and Warri-Parri Ridge similarly drains into Warriparri, the Sturt River. There are indeed numerous tilti 'native cherry' near Tilti Creek and there is a waterfall on Workanda Creek etc. However, in this case we can establish without doubt that the names were obtained from Kaurna wordlists. Cordes (1983:2) quotes a 1909 publication The National Parks of South Australia in which the Commissioners of the Park observed:

\begin{abstract}
Nomenclature -
A number of graceful native names have been given to the gullies and ridges of the Park. They are appropriate words, chosen from the vocabularies of aboriginal languages, but are not directly inherited from the wandering blackfellow, who has left no linguistic traces in this spot. They have superseded some of the names given by early settlers in the 'Tiers'. In the days of Government Farm Workanda was known as 'Waterfall Gully', Tarnma as 'Honeysuckle Gully', ... and the lower part of Minno Creek bore the homely title of the 'House Paddock Creek'.
\end{abstract}

Even though the quote indicates that the words were taken from 'the vocabularies of aboriginal languages', all the 'Native Names' listed in this publication are in fact clearly identifiable Kaurna words. Several of the spellings are, however, at variance with T\&S and other known Kaurna sources - Karka is given as 'sheoak', probably a simple typographical error, and Tarpurro is glossed as 'opossum' by the Park Commissioners, not 'possum skin drum' as in T\&S (1840) and Cawthorne (1844). Is there another Kaurna wordlist in existence that we have failed to locate? 
The map of Belair National Park included in Cotton (1953) lists these same Kaurna words in the names of ridges and creeks, though Perroomba appears as Peroomba and Tarpurro appears as Tarpurra. In addition, a number of arbours and other features have been added to the map, some of them adopting these same Kaurna names as follows:

Peroomba Arbour

Workanda Arbour

Minno Arbour

Tarnma Arbour

Karka Arbour

Karka Pavilion

Karka Oval

Tilti Arbour

Titti Dam <this is probably a misprint for Tilti. It is located at the head of Tilti Creek>

Some time after this, walking trails were added to the park. Three were named Workanda Track, Tilti Track and Yulti Wirra Track drawing on Kaurna names listed above. Additional names drew on both English and Indigenous names. The following appear to have been drawn from Aboriginal languages :

Moorowie Track (cf. T\&S murre- 'go, walk, travel' + kauwe 'water', i.e. 'running water' or murro 'dust' + kauwe 'water', a meaning more consistent with Cooper (1962:23) 'discoloured waterhole' and Endacott (1955:38) 'cloudy water')

Nookoo ${ }^{3}$ Track (cf. T\&S nguko 'a species of owl'; muka 'egg')

(cf. Cooper (1962:26) Nookoo 'valley')

Carawatha (cf. T\&S karra 'red gum tree'; karrawadlo 'shrub generally')

(cf. Tyrrell (1933) Carawatha (NSW) 'pine trees'; Cooper (1962:10) and Endacott (1955:17) Carawatha 'place of pine trees'; Sugden (n.d.) Karawatha 'place of pines')

Wypanda Track ${ }^{4} \quad$ (cf. Cooper (1962:39) Wypanda 'echo'. Note the proximity of Echo Tunnel under the railway line which the track passes.)

Wilyawa Track (cf. T\&S wilya 'foliage')

(cf. Cooper (1962:37) wilyawa 'scrub country')

Kaloola Track (cf. T\&S kudlilla 'rainy season, winter')

(cf. Cooper (1962:15) kaloola 'to climb')

\footnotetext{
Also spelt Mookoo on some maps.
}

4 The track, running alongside the railway line in the north of the park, is marked in the Street Directory, but not on the map issued at Belair National Park itself. 


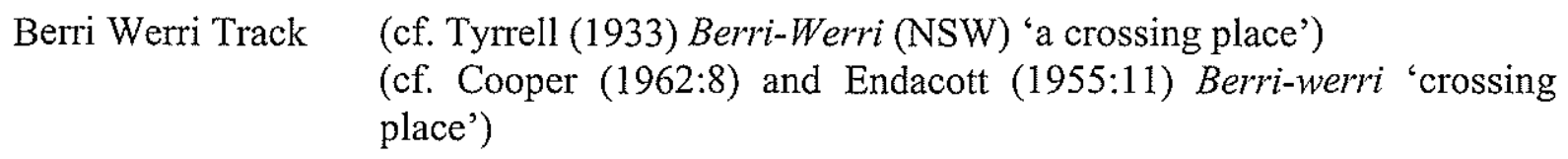

Thelmytre Track

Curta Track

(cf. Wyatt kerta 'a forest')

Yungurra Track

(cf. T\&S yangarra 'wife')

(cf. Cooper (1962:41) yungura 'crested pigeon')

While many of these words could have been taken from Cooper (1962), not all of them are listed there. A source has not been identified for Thelmytre. Perhaps it is not an Indigenous word at all.

It would appear that these names have been added to the map since 1953, but before 1968 (letter from Dene Cordes, 10 January 1996). However, it seems to be impossible to find out who placed them on the map, or indeed to be certain of the origins of some of these words. My own researches and enquiries with Belair National Park, the Department of Environment and Natural Resources and the Friends of Belair National Park have proved fruitless. Cordes suggests that it may have been Professor J. B. Cleland.

While none of the Indigenous names in use at Belair is an original retention, clearly the methods used by the Park Commissioners at the turn of the century to apply Kaurna names were well thought-out and well motivated. This contrasts with the importation of names from out of the area in the 1950s or 1960s, a practice that is quite inappropriate and superficial in the eyes of Kaurna people.

However, these activities are not the main focus of this paper. Rather, we intend to investigate the use of Kaurna names by Kaurna people themselves, or by government agencies and other bodies who are in consultation with and working at the direction of the Kaurna community. We are interested in investigating naming activity that serves to increase awareness of the Adelaide Plains as Kaurna country with an Indigenous history, so often overshadowed and obliterated by colonisation, urbanisation and development.

\section{KAURNA NAMES PROMOTED BY THE INDIGENOUS COMMUNITY}

In the case of Kaurna, little knowledge of the language is retained within the community. Knowledge of Indigenous placenames of the Adelaide Plains not already on the map is derived solely from archival material, though it is possible that some additional information may be held in the oral traditions of certain Nunga families.

Two decades ago Kaurna people started to turn to their own languages as a source of names for a variety of purposes. The establishment of Warriappendi Alternative School in 1980 was the first instance of the bestowal of a Kaurna name that was instigated and controlled by Kaurna people. Since then, Kaurna people, and others, have been turning to the historical materials increasingly as a source of names. This activity has extended to the reinstatement and institution of toponyms in Kaurna country, including metropolitan Adelaide.

Warriparinga, on the Sturt River, Marion, is an important case. This site is highly significant for the Kaurna people (see, for instance, Williams \& Chapman 1995:89) because of its centrality in the Tjilbruke Dreaming story which tells of the creation of springs and other sites to the south of Adelaide and of the iron pyrites deposits at Brukunga. Warriparinga marks the site where Kulultuwi, Tjilbruke's nephew, was killed. As such, it is recognised as 
the start of the Tjilbruke Dreaming track. It was from here that Tjilbruke collected his nephew's body, wrapped it up and carried it down the coast. The Kaurna name was recorded by several observers as follows:

\begin{tabular}{|c|c|}
\hline Warriparri & the Sturt River (T\&S 1840:73) \\
\hline War-rey par-rey & $\begin{array}{l}\text { the creek that runs from the hills into Holdfast Bay (Williams } \\
1840 \text { ) }\end{array}$ \\
\hline wari pari & $\begin{array}{l}\text { Sturt River meaning 'wind river' or 'river of the west wind' } \\
\text { (Black 1920:82) }\end{array}$ \\
\hline War:pari & Sturt Creek (Tindale 1987:8) \\
\hline Walpari & on Sturt Creek at Marion (Berndt \& Berndt 1993:233) \\
\hline Warriparri & $\begin{array}{l}\text { Sturt River meaning 'creek fringed with trees' (Cockburn } \\
\text { 1990:209) }\end{array}$ \\
\hline Warri-Pari & Sturt River meaning 'The Throat River' (Webb 1936-37:308) \\
\hline Warreparinga & Sturt Creek district 'windy river place' (Cooper 1952:28) \\
\hline Warriparri & Sturt Creek 'windy river' (Cooper 1952:28) \\
\hline
\end{tabular}

Black's (1920) recording probably indicates that it was still known by Ivaritji, recognised as the so-called 'last speaker' of Kaurna, whilst Berndt's and Tindale's recordings indicate that the name was known to their Ngarrindjeri informants in the 1930s and 1940s.

Until recently the Warriparinga site has been officially known as Laffers Triangle, whereas the river itself has been, and still is, known as Sturt River. However, the name Warri Parri Drive has been applied to a street in the nearby suburb of Flagstaff Hill. This street is adjacent to the Sturt Gorge Recreation Park which straddles the Sturt River behind Flinders University. Incidentally, the nearby suburb of Warradale was named in 1917 by George Hamilton, whose family were early residents in the district. He knew that Warraparinga was the rightful name for the Sturt River in that vicinity, but considered it "too long to become popular and substituted "dale" for "paringa"" (letter written by A. Hiscock, 4 July 1940).

In 1992, a proposal ${ }^{5}$ was put forward by Paul and Naomi Dixon for the establishment of the 'Warriparinga Interpretive Centre', though the site itself was still being referred to as Laffers Triangle (see Boynes 1992). A local environment group initially known as The Friends of Laffers Triangle became known as Friends of Warriparinga in 1992 or 1993. The name was soon applied to the entire reconciliation project planned for the site, no longer just the planned interpretive centre. At some time after 1992, the name was applied to the entire site. An article reporting on an interview with Paul and Naomi Dixon in the Salisbury, Elizabeth, Gawler Messenger (19 October 1994:5) refers to the 'Warriparinga area'. The site is now officially known as the Warriparinga Reserve and the adjacent wetland established in 1998 was named Warriparinga Wetland.

The site in 1999 was virtually only referred to as Warriparinga by the Kaurna community, environment groups, the Marion City Council and the general public alike. Today, many are

\footnotetext{
This proposal was taken from Georgina Williams' application to Susan Lenehan for the protection of Tjirbruki sites and the sustaining of the family clan group and the Kaurna peoples.
} 
not even aware of the existence of any other name. The name has been fully accepted as the name for the site almost totally precluding the use of other names.

In April 1997 a new wetlands reserve not far from Warriparinga was named Tartonendi ${ }^{6}$ by the Marion City Council and a plaque erected reading: 'Tartonendi. This Reserve is named Tartonendi which is a Kaurna word meaning "transforming the land into wetlands". The Kaurna people are the original inhabitants of the Adelaide Plains'.

\section{ADELAIDE CITY CASE STUDY}

The Adelaide City Council area, consisting of the city square, North Adelaide and the surrounding parklands, is a good case study in which to investigate issues associated with Indigenous placenames and their reinstatement.

Within this area there are just three names on the map of Indigenous origins in official use - Moonta Street, Morialta Street and Medindie Road, all of them minor thoroughfares. Moonta derives from Yorke Peninsula, having Narungga origins. Morialta is taken from Morialta Falls in the eastern foothills (Morialta possibly derives from mari 'east' + yertalla 'cascade') while Medindie Road is named after the adjoining suburb to which it leads. Its meaning is unknown, though it may derive from mettindi 'to steal'. Tindale (1974:213) refers to the 'Medaindi (horde living near Glenelg)' with a variant spelling Medaindie, though he does not suggest an etymology. So none of the names in use (ignoring the names applied to buildings and organisations, most of which have been adopted recently) ${ }^{7}$ is a name employed by Kaurna people to refer to a natural feature in the area.

The only possibility of an original retention still in use is that of Pinky Flat near the Adelaide Oval which may derive from Kaurna pingko 'bilby' (Praite \& Tolley 1970:139ff.), though it and some other sources say it derives from English. According to Manning (1986:169) 'during the depression years of the 1930s, it was used as a camp by unemployed, and cheap wine called "Pinky" was consumed there'. Pinky or pinkie appears in the Australian National Dictionary meaning both 'bilby' and 'cheap or home-made (fortified) wine' (Hughes 1989:411), giving further credence to both etymologies.

However, names for a number of geographical features in the area were recorded by several observers. The Torrens River was recorded as Karrauwirraparri (T\&S 1840:75), the 'redgum forest river'. Wyatt (1879) records Korra weera, yerta and perre 'Adelaide, and the Torrens': so it would appear that the land surrounding the Torrens was known as Karrawirrayerta.

6 The word tarto 'low, swampy country' appears in T\&S. The word tartonendi was formed by myself through the addition of the inchoative suffix. That is, tartonendi literally means 'becoming low, swampy country' (i.e. being transformed into wetlands).

7 A number of Aboriginal organisations bearing Kaurna names and names drawn from other Indigenous languages including Ngarrindjeri and Pitjantjatjara are located in the Adelaide City Council area. These include Tandanya, Kumangka, Patpa Warra Yunti and Nunkuwarrin Yunti. Educational institutions, notably the University of Adelaide and the University of South Australia, have adopted a number of Kaurna names for various buildings and centres, including Wilto Yerlo, Mattanya Housing, Wirranga Health Service and the Yungondi Building. Several businesses in the area also bear Indigenous names. These include Ngapartji multimedia consortium and Wirranendi urban ecology centre. 
Other names recorded include:

$\begin{array}{llr}\text { Kaurna name } & \text { meaning } & \text { English name/location } \\ \text { Tandanya } & \text { 'red kangaroo rock' } & \text { Adelaide south of the Torrens } \\ \text { Piltawodli } & \text { 'possum home' } & \text { 'Native Location' } \\ \text { Tambawodli } & \text { 'plain house' } & \text { 'Emigration Square' } \\ \text { Tinninyawodli } & \text { 'rib house' } & \text { 'the Ironstores' } \\ \text { Kainkawirra } & \text { 'redgum forest' } & \text { North Adelaide } \\ \text { Kainkawirra } & \text { 'redgum forest' } & \text { lake in Botanical Gardens } \\ \text { Ngamaji } & \text { unknown } & \text { GPO } \\ \text { Walinga } & \text { 'house place' } & \text { city of Adelaide }\end{array}$

At least one of these names clearly refers to a post-colonial imposition on the landscape. Tinninyawodli (lit. 'rib house') was the name given to the 'Ironstores' or Colonial Store. It appears that the word for 'rib' was extended to 'iron' ${ }^{8}$ probably because iron was imported into the colony in lengths resembling a rib. Other names, such as Walinga 'house place' and Tambawodli 'plain house' referring to Emigration Square where there were rows of temporary huts and tents to house new arrivals in the colony, are probably similar.

\section{THE ADELAIDE CITY COUNCIL PLACENAMING PROPOSAL}

In December 1996 I (Amery) was approached by the Adelaide City Council to research original names and the history of the Kaurna people within the Adelaide city and North Adelaide areas under the jurisdiction of the Council. As part of the reconciliation process, a naming proposal was developed which suggested Kaurna names for the 29 parks within the parklands and names for the seven city squares. In 1997 a set of naming principles was developed (see Appendix 1) which promoted the use of original names. Where these names were not recorded, I proposed names that related to a particular plant species found in the area or known to have existed there. I also proposed several names that related to current use of the park. For instance, I suggested naming Park 02 Padipadinyilla 'swimming place' because of the presence of the Aquatic Centre there. Furthermore I proposed that the squares and four high profile parks be named after prominent Kaurna individuals, such as Mullawirraburka 'King John', while the golf course greens at the Piltawodli 'Native Location' site on Park 01 could be named after Kaurna children and adults who were known to have lived there. (The full proposal is included in Appendix 2 of this paper.)

While few of these names are original retentions, the names applied do give a Kaurna perspective and serve to remind us of an Indigenous heritage through the names of prominent leaders known to have frequented the area, and the names of Indigenous plants that formerly dominated the landscape. It is important, though, that the signs be accompanied by information, so that residents and visitors have the opportunity to appreciate deeper understandings of Kaurna culture and history.

\footnotetext{
Wyatt (1879:20) gives tinninye 'iron' and tinninye werle 'an iron store', though he does not list a word for 'rib'. T\&S give tinninya 'rib' and Tinninyawodli 'the Ironstores'.
} 
The Adelaide City Council considered five Kaurna names at its meeting of 13 March 2000 (communication from General Manager City Strategy to the Strategy and Policy Committee on 13 March 2000 re Kaurna Naming [C] (1999/00996)). The Council made a formal request to the Geographical Names Board to dual name the Torrens River as Karrawirraparri (lit. 'redgum forest river'). Karrawirra Parri was officially adopted in November 2001. Four additional names of parks (previously unnamed) were also adopted by the council as follows:

$\begin{array}{lll}\text { Piltawodli } & \text { Park } 01-\text { North Adelaide golf course } & \text { (lit. 'possum house') } \\ \text { Karrawirra } & \text { Park 12 - near University footbridge } & \text { (lit. 'redgum forest') } \\ \text { Wirranendi } & \text { Park 23 - includes West Terrace cemetery } & \text { (lit. 'being transformed into forest') } \\ \text { Tambawodli } & \text { Park 24 - Glover Ave and West Terrace } & \text { (lit. 'plain house') }\end{array}$

The issue was reported in The Advertiser (15 March 2000:11) in an article entitled 'Reconciliation's sign of the times' which quoted Kaurna Elder Lewis O'Brien. Signage for these four parks was erected and unveiled on 14 November 2001 with the Council announcing the adoption of a further 19 Kaurna names for the remaining unnamed parks. Dual naming of Victoria Square as Tarndanyangga was adopted by the Council on 27 May 2002. However dual naming of the remaining squares and parks that already bear English names has yet to be adopted.

\section{PILTAWODLI}

Piltawodli, the site of the 'Native Location' on the banks of the Torrens River, is perhaps the most important of the five names adopted by the Adelaide City Council in 2000 . Even before its official adoption on 13 March 2000 , this name was becoming better known within the community. This was especially so after the Journey of Healing reconciliation event, attended by several thousand people on 26 May 1999. Shortly afterwards, an article entitled "Piltawodli: remembering the "possum house"' appeared in the Adelaidean (14 June 1999:4).

The Piltawodli site, currently a golf course with few visible signs of the former existence of the 'Native Location', was given some recognition in the literature by Foster (1990) and since that in Amery (1998; 2000), Hemming and Harris (1998) and Harris (1999). I first took a group of students who were studying Kaurna language at Para West Adult Campus on an excursion to Piltawodli in 1997. Since then Lewis O'Brien, Cherie Watkins, Karl Telfer and I have accompanied students from the University of Adelaide, Tauondi College, Kaurna Plains School and Inbarendi College, a large group of teachers, as well as small groups of international visitors. In this way it has been gaining increasing informal recognition.

Piltawodli is a particularly important site, for it was here that almost everything we know of the Kaurna language was recorded. At this site we also see the beginnings of policies in South Australia which separated Aboriginal children from their families - policies that gave rise to the 'stolen generations'. Because of its importance, a plaque now marks the site (see Appendix 3 for the text of the plaque). A mock-up prepared by design staff within the Adelaide City Council was put on display at the site on 26 May 1999. The Council set aside $\$ 5,000$ for its establishment and an equivalent amount has been donated by the Lutheran Church. The plaque was unveiled by Kaurna Elder Doris Graham and incoming Lord Mayor Alfred Huang on 26 May 2000 to mark the anniversary of National Sorry Day during the Journey of Healing reconciliation event. Those who attended included Kaurna people, 
descendents of the German missionaries, representatives of the South Australian Government, the Lutheran Church and the Adelaide City Council, a large number of school children and members of the public.

The Piltawodli site has become an important focus for the Kaurna language program at Kaurna Plains School and the name is becoming known within the Kaurna community.

\section{REINSTATING KAURNA NAMES}

As the Adelaide City Council Placenaming Proposal demonstrates, only a certain amount can be done in terms of reinstating the rightful original names. Owing to the paucity of records, the potential for reinstating authentic Indigenous toponyms on the Adelaide Plains is limited. However, there are a number of important Kaurna names known from the historical record, where dual naming would be a possibility. These include:

$\begin{array}{lll}\text { Yertabulti } & \text { 'land of sleep or death' } & \text { Port Adelaide } \\ \text { Kaleeya Kaleteeya } & ? & \text { Gawler } \\ \text { Pattawilya } & \text { 'gum tree foliage' } & \text { Glenelg } \\ \text { Karraundongga } & \text { 'redgum chest place' } & \text { Hindmarsh } \\ \text { Warkowodliwodli } & \text { '? houses' } & \text { Klemzig } \\ \text { Putpayerta } & \text { 'fertile ground' } & \text { Lyndoch Valley } \\ \text { Yerltoworti } & \text { '? tail' } & \text { Hindmarsh Valley } \\ \text { Parriworta } & \text { 'river behind' } & \text { Hutt River } \\ \text { Witongga } & \text { 'reed place' } & \text { The Reedbeds (Fulham) }\end{array}$

There are basically two approaches we can use in the reinstatement of Kaurna names. We can seek to make them official by working through the relevant authority having jurisdiction over naming in that area for the purposes proposed. For instance, we can lobby for their placement on the map by the Geographical Names Board, local council etc. Alternatively, we can simply begin to use them. Of course both processes can work together, but the latter is much more meaningful. As Bill Watt pointed out on ABC Radio (25 October 1999), the technical process of changing a name is easy. More demanding is the need to conduct the appropriate consultation and develop a sense of ownership of the changes within the community. In 1918, many German placenames in South Australia were removed and replaced with English and Indigenous names. However, in most cases the community did not embrace the changes and following the cessation of hostilities many of them reverted to their German names.

It is evident that many people in the community would like to see the restoration of Indigenous names, but there are strong indications that they are still a minority. Over the last few years with the restructuring and amalgamation of local councils, names have been needed for the new entities. Several times I have been asked for advice by councils themselves, councillors and residents who are wanting to promote Kaurna names, and especially original names from the respective areas. Alternatives have been put forward, but in every case non-Indigenous names have won the day. Five years ago, the Australian Labor Party suggested that the name for Adelaide should be changed to Kaurna in the year 2000 (The Advertiser, 24 November 1994:1-2), but only a small minority interviewed by The Advertiser 
supported the proposal. Similarly, when Mark Brindal MP proposed changing the name of Victoria Square to Tandanya, most callers to the ABC talkback program (ABC Radio, 25 October 1999) did not support the idea. So a lot of groundwork needs to be done before Kaurna names can be reinstated in a way that is acceptable to and owned by the community at large.

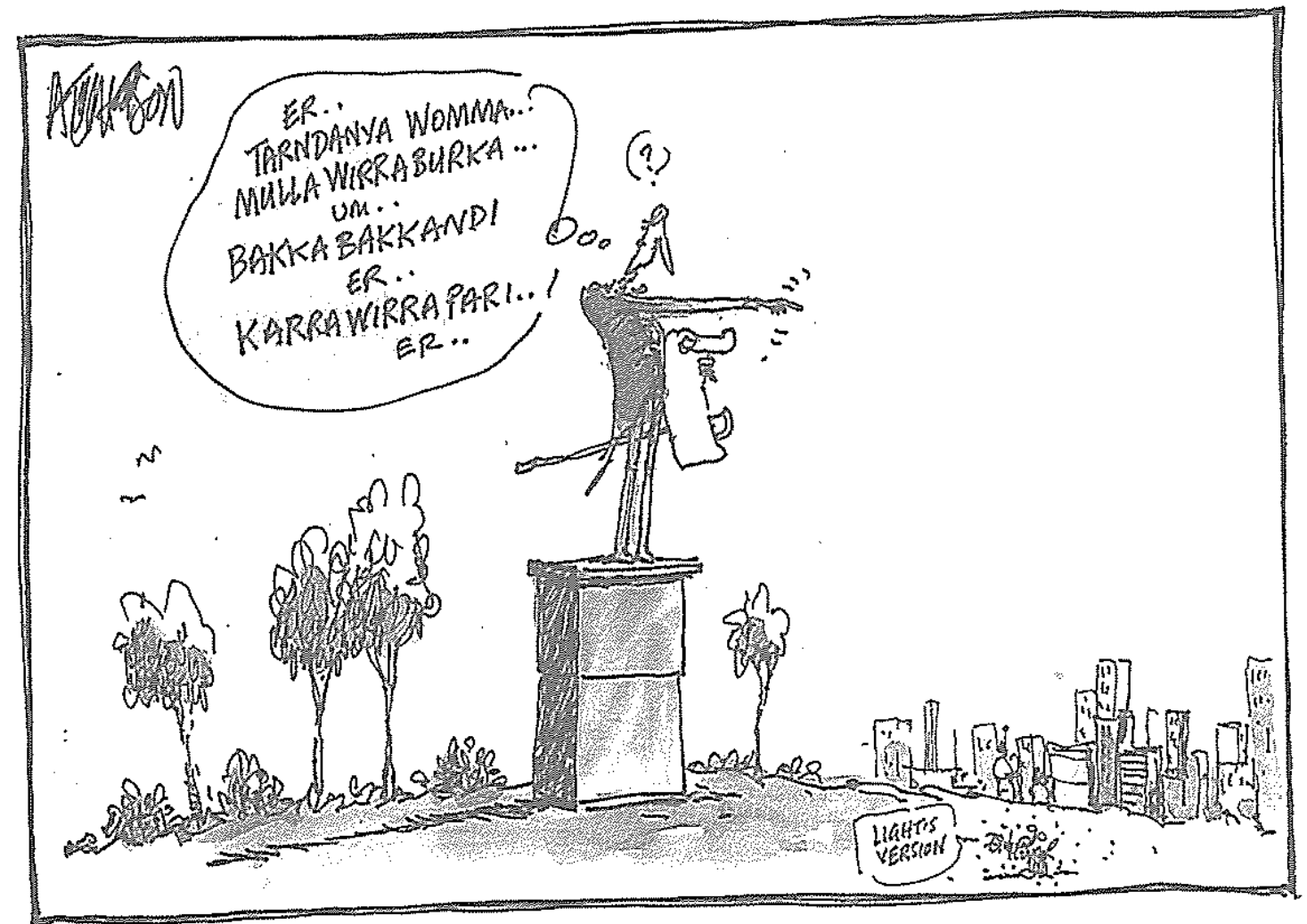

Figure 1: Cartoon from The Advertiser, 16 March 2000, courtesy of Michael Atchison

We would argue that the best way to ensure the reinstatement of Kaurna names, where these are known, is for us to simply begin to use them in our teaching programs, our writings and in our everyday conversations, and to familiarise the public with these sites and their history. I (Amery) recall back in 1974 during an acute accommodation crisis at the Australian National University, some of us were allowed to occupy rooms at Toad Hall before its completion and before it had been named officially. It was then referred to by the administration as 'the Fourth Hall of Residence'. We made a rough official-looking sign out of polystyrene and had mail sent to us at Toad Hall. In the end, the administration had no option but to follow suit.

If Kaurna names are to be accepted officially, then we need to do a lot of work to promote them within the community. To totally replace high-profile existing names, such as Victoria Square, is exceedingly difficult. Of course it can be done as was the case with St Petersburg becoming Leningrad and Batavia becoming Jakarta, but these were renamed following revolution and expulsion of a colonial power. Far less threatening than total replacement is the application of a Kaurna name alongside an existing name. Fortunately in South Australia such legislation exists, known as the Dual Naming Policy, which has been applied in the Flinders 
Ranges, and only recently within Kaurna country. ${ }^{9}$ Under the Dual Naming Policy, the Indigenous name may eventually gain more popularity than the existing English name, as is the case with Uluru which was initially introduced alongside of Ayers Rock in the face of considerable resistance.

In 1991 the Victorian Labor government adopted Geriwerd, the Jardwadjali word for 'mountain' for the Grampians National Park. The name was dropped by the newly elected Kennett Liberal government in 1992 following the tabling of a petition of some 57,000 signatures. Despite this, according to The Age (15 March 2000:6), 'the park's ranger-incharge, Mr Graham Parkes, said yesterday that the park's management, locals and tour operators continued to use Geriwerd'.

Of course, for locations such as Tambawodli or Piltawodli, which currently do not have an established English name, the process is much easier, but even here resistance can be expected.

\section{AUTHENTICITY AND INTEGRITY OF NAMES}

In reinstating or placing Indigenous names on the map, we need to be sure that they are correct and appropriate. We have already seen in the Adelaide City Council area and Belair National Park that a number of names have been drawn from out of the area and from other Indigenous languages. Norman Tindale, of the South Australian Museum, was a prolific writer and compiled placename card files and annotated maps from many parts of Australia, including the Adelaide Plains, with Indigenous names. Many of his published papers on ethnography and Dreaming stories are filled with placenames. So Tindale's work is a logical source of Indigenous placenames. However, much care needs to be taken with Tindale's materials. Firstly, there is an orthographic problem. Tindale used a modified IPA orthography which uses ' $\mathrm{y}$ ' where others use 'ng'; and ' $\mathrm{j}$ ' where other writers and the general public would write ' $y$ '. Tindale's orthography is not designed for or suited to signage and necessarily causes mispronunciation of the words. In a display at Mount Lofty Summit established in 1997, a panel telling of the Urebilla story talks of 'Jureidla, the two ears of the great ancestral giant Urebilla (pronounced Yura-billa)'. Will visitors link Jureidla with Uraidla? Certainly the visitor information desk was not aware of the connection when I (Amery) rang on 4 November 1997. Perhaps more serious in relation to names on the Adelaide Plains, is the fact that most of his sources were Ngarrindjeri people from the Lower Murray and Coorong. Consequently, many of the names he imposed on the Adelaide Plains are Ngarrindjeri names or Ngarrindjeri adaptations of Kaurna names. For instance, he records the name for Glenelg as Pattawilyangk with the Ngarrindjeri locative suffix $-n g k$ as opposed to Pattawilyangga with the Kaurna suffix -ngga. Many other names begin with ' $r$ ' or '1' (see Amery 1998:199-202, 207-208; Tindale 1987). Yet Kaurna words, as we know them from all of the Kaurna sources, never commence with ' $r$ ' or ' $l$ ' and they clearly have Ngarrindjeri origins. These words should be avoided or attempts should be made to ensure that these words are Kaurnaised Kaurna suffixes should be used to replace the Ngarrindjeri suffixes. The Kaurna sources record a number of names, such as Ngalta 'the Murray River' and Parnka 'Lake Alexandrina'

The adoption of Karrawirra Parri for the Torrens River by the Adelaide City Council was ratified by the Geographical Names Board in November 2001. This is the first application of the Dual Naming Policy involving a Kaurna name. 
(T\&S 1840:75) for locations deep inside Ngarrindjeri territory, and no-one would suggest that these Kaurna names should be accepted as the official names for those locations.

\section{CONCLUSION (WILLIAMS)}

These final remarks are my views on placenames and their rehabilitation. As a Kaurna person, I have grown up with oral traditions and understandings about places and their significance that do not necessarily appear in the historical record. As a child, I was in the presence of old people and my grandfather who shared the stories of the spirit beings. As a younger woman I travelled over the country with my dad to places on the Adelaide Plains and surrounding hills. He explained these things to me as he remembered stories which had been passed on to him.

The placenames that have survived in an Anglicised form are part of the story, law and lore of the land formations and places in which they are situated. These placenames are the 'skeletal remains' of the historical surviving reality of Kaurna First Nation peoples, once a peaceful and intact body of lore/law of the land.

The word Yankalilla, derived from yernkandi 'to hang down, on; to join; impart; infect, as with a disease; to depend' (T\&S 1840:61) + -lya + -illa 'place' (i.e. 'place of the fallen bits' Manning 1986:237; see Amery, this volume, for further details), is part of the law ceremony mortuary ritual and is of immense importance in reclaiming, through language recovery, the understanding of Kaurna Aboriginal people's rightful place and function in the framework of one's identity with the law of the land, and the spiritual and custodial responsibilities in everyday life. Tjirbruki, carrying the remains of his dead nephew's deteriorating and flaking body, falls to the ground at Yankalilla.

The word Onkaparinga derives from ngangkiparringga (lit. 'woman river place' or 'women's river') which leads into deeper insider understandings that we will not go into here. Ngurlongga or Horseshoe Bend on the Onkaparinga River is probably derived from nurlo 'curvature, corner' + -ngga 'place'. From these pieces and fragments of the remains of a hunter-gatherer society can be seen the horrific effects of the dispossession process.

I believe that the placing of Kaurna names to places today creates identity of a superficial nature unless they are relating to some source of relationship to the land and through this to the spirit of the land. The language of the Kaurna, and all other Aboriginal language names, should stay true to the original nature of the land and spirit relationship or we are contributing to even further dispossession by putting anything anywhere because some people might think this is a 'nice' gesture of remembrance to a now extinct people to meet a fashionable and acceptable fetish of the day.

When we name a building, we draw on what the building might be used for. The same would apply to an organisation - the name would have meaning and relate to the purpose, function or place. For example, Yaitya Makkitura 'Indigenous mirror' for the new Indigenous film, screenwriters and multimedia incorporated body in South Australia, founded by David Wilson, a Kaurna descendant/survivor. This has been how we have approached the way to best use the Kaurna language for the purposes of being a part of our life and identity in the contemporary Nunga world today.

By using our language reclamation in this way, we identify with the purposes served by the language in the reconstruction of identity from the roots remaining. Naming activity that is not rooted in the land and in the people of the land runs the risk of being a shallow and meaningless activity that misappropriates our language and culture. 


\title{
APPENDIX 1
}

\section{STRATEGIES FOR NAMING PARKS}

\author{
Rob Amery
}

\section{ORIGINAL NAME}

The first choice for a park name is obviously to use the original name (e.g. Ngamatyi for 'Victoria Square') where that name is known. In the case of Ngamatyi, the Kaurna name could be used alongside the English name according to the Dual Naming Policy. Unfortunately, few original names survive within the Adelaide City Council area. They include Tarndanya, Karrawirraparri, Piltawodli, Tambawodli, Tinninyawodli, Ngamatyi, Kainka Wirra and possibly Pinky Flat.

\section{NAME RELATING TO A PARTICULAR TYPE OF FLORA FOUND IN THE AREA OR KNOWN TO HAVE EXISTED THERE}

Advice has been sought from Waldo Bushman regarding the indigenous flora in different localities within the Adelaide City Council area. In a few cases there are remnant trees and plants surviving, but in many cases the name is based on a guess taking topography and soil types into account.

A number of food plants are believed to have been widely distributed across the Adelaide Plains. It is not possible to identify the precise species of many of these recorded plant names, as the descriptions provided are inadequate. Some of these plant names have been used to name various parks, though we cannot be certain that the said plant was prevalent in the particular area covered by the park.

All of the plant terms used (except for kurra 'blue gum' and tandotitte 'native lilac') were recorded by Teichelmann and Schürmann (1840) and some of these terms are confirmed by other sources. Teichelmann and Schürmann lived at Piltawodli opposite the Adelaide Gaol. There is a high probability that the terms they recorded are local terms.

\section{NAME RELATING TO CURRENT USE OF THE PARK}

Several suggested names relate to current use or activities habitually carried out within that area of the parkland. Such names include Bakkabakkandi 'to trot', Nanto Womma 'horse plains', Padipadinyilla 'swimming place' and Wikaparndo 'netball park'.

\section{NAMED AFTER KAURNA INDIVIDUALS}

Names of Kaurna individuals have been suggested for four high-profile parks, the wives of the three burka 'elders; leaders' at the time of colonisation and Pangki Pangki, a trusted Kaurna guide and tracker who accompanied Moorhouse and Tolmer up the Murray River to Lake Bonney and the Rufus River. These names could be used in addition to existing names. 
It is also suggested that the names of the three burka, Mullawirraburka 'King John', Kadlitpinna 'Captain Jack' and Ityamaiitpinna 'King Rodney', and the names of two prominent Kaurna women, Ivaritji and Kudnarto, be applied to the squares under the Dual Naming Policy.

In addition, the greens in the golf course in Park 01 could be named after children who were known to have attended the 'Native School' at Piltawodli located within the current precincts of the course and with the names of Kaurna adults known to have lived at the 'Native Location'. Refer to the paper on Kaurna individuals.

A plaque could also be erected on the site of Tinninyawodli 'The Ironstores' shown on Kingston's (1842) map, as a memorial to the two men, Bakkabarti Yarraitya and Parudiya Wangutya, who were hung there on 31 May 1839.

\section{APPENDIX 2}

\section{Proposal for park names in Adelaide City Council area ${ }^{10}$}

\begin{tabular}{|c|c|c|c|}
\hline No. & Kaurna name & English name & Notes \\
\hline 01 & $\begin{array}{l}\text { Piltawodli } \\
\text { 'possum place' }\end{array}$ & $\begin{array}{l}\text { Prev. 'Native } \\
\text { Location' } \\
\text { Montefiore Park }\end{array}$ & $\begin{array}{l}\text { City of Adelaide Golf Links. Par } 3 \text { of Golf } \\
\text { Links is the actual Piltawodli site. } \\
\text { pilta 'possum' + wodli 'house; camp; place' } \\
\text { Tinninyawodli 'The ironstores' (tinninya } \\
\text { 'rib' + wodli 'house'), site of } 1839 \\
\text { hangings, is also located within the South } \\
\text { Course. }\end{array}$ \\
\hline 02 & $\begin{array}{l}\text { *Padipadinyilla } \\
\text { "swimming place" }\end{array}$ & & $\begin{array}{l}\text { Location of Adelaide Aquatic Centre. } \\
\text { padipadinya 'swimming' < padendi 'to } \\
\text { swim' + -illa 'LOC' }\end{array}$ \\
\hline 03 & $\begin{array}{l}\text { Kandarilla } \\
\text { 'kandara root } \\
\text { place' }\end{array}$ & & $\begin{array}{l}\text { kandara T\&S 'native vegetable resembling } \\
\text { radish' + -illa 'LOC' }\end{array}$ \\
\hline 04 & $\begin{array}{l}\text { Kangattilla } \\
\text { 'kangatta berry } \\
\text { place' }\end{array}$ & & $\begin{array}{l}\text { Croquet Lawns; adjacent reservoir } \\
\text { kangatta T\&S 'a kind of berry eaten by the } \\
\text { natives' }+- \text { illa 'LOC' }\end{array}$ \\
\hline 05 & $\begin{array}{l}\text { Ngampa Yerta } \\
\text { 'ngampa root } \\
\text { ground" }\end{array}$ & & $\begin{array}{l}\text { ngampa T\&S 'a kind of native vegetable' } \\
\text { Wyatt umba 'edible root' [microseris] } \\
\text { yerta 'ground' }\end{array}$ \\
\hline 06 & $\begin{array}{l}\text { Nanto Womma } \\
\text { 'horse plain' } \\
\end{array}$ & & $\begin{array}{l}\text { Horse agistment, playground, tennis } \\
\text { nanto 'horse' + womma 'plain' }\end{array}$ \\
\hline 07 & $\begin{array}{l}\text { Kuntingga } \\
\text { 'kunti root place' }\end{array}$ & & $\begin{array}{l}\text { kunti } \mathrm{T} \& \mathrm{~S} \text { 'a root of red colour and bitter } \\
\text { taste, which the natives roast and eat' } \\
+-n g g a \text { 'LOC' }\end{array}$ \\
\hline
\end{tabular}

10 23 of these names have now been officially adopted by the Adelaide City Council. In the process some minor changes were made to this proposal. For example, the names for Parks 24 and 25 were swapped around and Park 15 was changed to Ityamaiitpinna. 


\begin{tabular}{|c|c|c|c|}
\hline 08 & $\begin{array}{l}\text { Barnguttilla } \\
\text { 'barngutta root } \\
\text { place' }\end{array}$ & & $\begin{array}{l}\text { barngutta T\&S 'native root; potato' } \\
\text { This tuber most closely resembled the } \\
\text { European potato. }\end{array}$ \\
\hline 09 & $\begin{array}{l}\text { Tidlangga } \\
\text { 'tidla root place' }\end{array}$ & & $\begin{array}{l}\text { Prince Alfred College Sportsground } \\
\text { tidla T\&S 'a bulbous root eaten by the } \\
\text { natives' }\end{array}$ \\
\hline 10 & $\begin{array}{l}\text { Warnpangga } \\
\text { 'bulrush root place' }\end{array}$ & & $\begin{array}{l}\text { University of Adelaide Sportsground; } \\
\text { archery club; Soldiers Memorial Gardens; } \\
\text { ACC Nursery; northern bank of Torrens } \\
\text { warnpa 'bullrush root', a staple food source } \\
\text { prolific along the Torrens and other } \\
\text { waterways; + -ngga 'LOC' }\end{array}$ \\
\hline 11 & $\begin{array}{l}\text { Kainka Wirra } \\
\text { 'Eucalypt forest' }\end{array}$ & Botanic Park & $\begin{array}{l}\text { includes zoo; botanical gardens. } \\
\text { Original name from Ivaritji for waterhole, } \\
\text { now the main lake in the botanical gardens. } \\
\text { River red gums would have been the } \\
\text { dominant eucalypt species there. Perhaps } \\
\text { kainka is a synonym for karra 'river red } \\
\text { gum' + wirra 'forest' }\end{array}$ \\
\hline 12 & $\begin{array}{l}\text { Karra Wirra } \\
\text { 'River red gum } \\
\text { forest' }\end{array}$ & & $\begin{array}{l}\text { precise location unclear. ? includes Grundy } \\
\text { Gardens and Angas Gardens; University } \\
\text { footbridge. Karrawirraparri 'red-gum forest } \\
\text { river' was the original name for the Torrens } \\
\text { which flowed through the karra wirra 'red } \\
\text { gum forest' }\end{array}$ \\
\hline 13 & $\begin{array}{l}\text { Mogata } \\
\text { wife of 'King John' } \\
\text { or Mullawirraburka }\end{array}$ & Rundle Park & $\begin{array}{l}\text { Light Horse Memorial } \\
\text { mogata (meaning unknown) }\end{array}$ \\
\hline 14 & $\begin{array}{l}\text { Tangkaira } \\
\text { wife of 'King } \\
\text { Rodney' or } \\
\text { Ityamaiitpinna } \\
\end{array}$ & Rymill Park & $\begin{array}{l}\text { Adelaide Bowling Club } \\
\text { tangkaira T\&S 'a species of fungus' } \\
\text { N.B. Tangkaira was a signatory of the } 1841 \\
\text { letter. She was also Ivaaritji's mother. }\end{array}$ \\
\hline 15 & $\begin{array}{l}\text { Wauwe } \\
\text { wife of Kadlitpinna } \\
\text { or 'Captain Jack' }\end{array}$ & & $\begin{array}{l}\text { CBC Oval; Glover Playground; centre of } \\
\text { Grand Prix circuit } \\
\text { wauwe 'female kangaroo' } \\
\text { Her name is spelt Wahwey in the original } \\
\text { source. }\end{array}$ \\
\hline 16 & $\begin{array}{l}\text { Bakkabakkandi } \\
\text { 'to trot; a term } \\
\text { applied to horses' }\end{array}$ & $\begin{array}{l}\text { Victoria Park } \\
\text { Racecourse }\end{array}$ & \\
\hline 17 & $\begin{array}{l}\text { Tuttangga } \\
\text { 'grass place' }\end{array}$ & & $\begin{array}{l}\text { croquet; tennis; oval; south-east corner } \\
\text { some original native grasses preserved here. } \\
\text { tutta 'grass; hay' + -ngga 'LOC' }\end{array}$ \\
\hline 18 & $\begin{array}{l}\text { Witangga } \\
\text { 'Peppermint gum } \\
\text { place' }\end{array}$ & & $\begin{array}{l}\text { Osmond Gardens; Himeji Gardens } \\
\text { wita 'peppermint gum' + -ngga 'LoC' }\end{array}$ \\
\hline
\end{tabular}




\begin{tabular}{|c|c|c|c|}
\hline 19 & $\begin{array}{l}\text { Pityarilla } \\
\text { 'marshmallow root } \\
\text { place' }\end{array}$ & & $\begin{array}{l}\text { Glover Playground; Bowling Club; } \\
\text { Equestrian Area } \\
\text { pityarra Teich 'edible root of the ngunna } \\
\text { marshmallow'; Wyatt peecharra 'mallow' } \\
\text { (a shrub) + -illa 'LOC' }\end{array}$ \\
\hline 20 & $\begin{array}{l}\text { Kurrangga } \\
\text { 'Blue gum place' }\end{array}$ & & $\begin{array}{l}\text { picnic areas; playgrounds } \\
\text { kurra 'blue ground' }+-n g g a \text { 'LOC' } \\
\text { [?? original source. Coora in Tauondi book] }\end{array}$ \\
\hline 21 & $\begin{array}{l}\text { Walyo Yerta } \\
\text { 'walyo root } \\
\text { ground' }\end{array}$ & & $\begin{array}{l}\text { Veale Gardens; Rose Garden; } \\
\text { Conservatory; restaurant; tramline } \\
\text { walyo 'edible white root resembling a } \\
\text { radish' + yerta 'ground' }\end{array}$ \\
\hline $\begin{array}{l}21 \\
W\end{array}$ & $\begin{array}{l}\text { Minno Wirra } \\
\text { 'golden wattle } \\
\text { grove' }\end{array}$ & & $\begin{array}{l}\text { Wattle Grove; Princess Elizabeth } \\
\text { Playground; Lundie Gardens; oval } \\
\text { minno 'golden wattle; wattle gum' + wirra } \\
\text { 'forest' } \\
\text { Minno was a staple food for the Kaurna. }\end{array}$ \\
\hline 22 & $\begin{array}{l}\text { *Wikaparndo } \\
\text { Wirra } \\
\text { 'netball park' }\end{array}$ & & $\begin{array}{l}\text { SA United Church Netball Assoc. courts } \\
\text { wika 'net' (wallaby or fish net) + parndo } \\
\text { 'possum skin ball' (used as a football) + } \\
\text { wirra 'forest; park' }\end{array}$ \\
\hline 23 & $\begin{array}{l}\text { *Wirranendi } \\
\text { 'to become wirra' }\end{array}$ & & $\begin{array}{l}\text { West Terrace Cemetery; oval playground; } \\
\text { Kingston Gardens; several surviving } \\
\text { indigenous plant species including native } \\
\text { apricot trees in West Terrace Cemetery. } \\
\text { wirra 'forest' + -nendi 'to be transformed } \\
\text { into' }\end{array}$ \\
\hline 24 & \begin{tabular}{|l|} 
Narnungga \\
'native pine place'
\end{tabular} & & $\begin{array}{l}\text { Adelaide High School; Ellis Park; oval } \\
\text { narnu 'native pine' }+-n g g a \text { 'LOC' }\end{array}$ \\
\hline 25 & $\begin{array}{l}\text { Tambawodli } \\
\text { 'plain house' }\end{array}$ & $\begin{array}{l}\text { prev. Emigration } \\
\text { Square }\end{array}$ & $\begin{array}{l}\text { sportsground; ANI oval } \\
\text { tamba 'plain' + wodli 'house; camp; place' }\end{array}$ \\
\hline 26 & $\begin{array}{l}\text { Wilyaru Yerta } \\
\text { 'Initiation Ground' }\end{array}$ & Adelaide Oval & $\begin{array}{l}\text { cricket; tennis; Creswell Gardens; } \\
\text { Pennington Gardens. The Adelaide Oval } \\
\text { itself could be named Tarndanya Womma } \\
\text { 'Adelaide Plain' } \\
\text { wilyaru 'the final stage of initiation which } \\
\text { includes cicatrisation' + yerta 'ground' }\end{array}$ \\
\hline 27 & $\begin{array}{l}\text { Tainmundilla } \\
\text { 'mistletoe place' }\end{array}$ & Bonython Park & $\begin{array}{l}\text { Adelaide Gaol; Police Barracks; SES HQ } \\
\text { tainmunda 'mistletoe' + -illa 'LOC' } \\
\text { Mistletoe was prevalent wherever redgums } \\
\text { were located, especially along the Torrens. }\end{array}$ \\
\hline 28 & $\begin{array}{l}\text { Pangki Pangki } \\
\text { name of Kaurna } \\
\text { tracker and guide }\end{array}$ & Palmer Place & $\begin{array}{l}\text { pangki pangki (meaning unknown) } \\
\text { Pangki Pangki accompanied Moorhouse to } \\
\text { Lake Bonney and the Rufus River in } 1841 \text {. }\end{array}$ \\
\hline
\end{tabular}




\begin{tabular}{|l|l|l|l|}
\hline 29 & $\begin{array}{l}\text { Tandotittingga } \\
\text { 'native lilac place' }\end{array}$ & Brougham Place & $\begin{array}{l}\text { The native lilac flowers on the shortest day } \\
\text { of the year - a sign of hope. Note } \\
\text { proximity to Adelaide Children's Hospital. } \\
\text { tandotitte 'native lilac' + -ngga 'LOC' }\end{array}$ \\
\hline $\begin{array}{l}\dagger \text { Tarnda Kanya } \\
\text { 'red kangaroo rock' }\end{array}$ & Elder Park & $\begin{array}{l}\text { tarnda 'red kangaroo' (principal totem of } \\
\text { the Adelaide clan) + kanya 'rock' being the } \\
\text { likely source of Tarndanya, the Kaurna } \\
\text { name for Adelaide. }\end{array}$ \\
\hline
\end{tabular}

\section{Squares}

\begin{tabular}{|l|l|l|}
\hline \multicolumn{1}{|c|}{ Suggested Kaurna name } & \multicolumn{1}{|c|}{ Current name } & \multicolumn{1}{c|}{ Notes } \\
\hline $\begin{array}{l}\text { (mgamatyi } \\
\text { (meaning unknown) }\end{array}$ & Hindmaria Square & $\begin{array}{l}\text { Ivaritji was the source of the name } \\
\text { Ngamatyi, spelt Ngamaji in the original } \\
\text { sources. She said it was the site where the } \\
\text { GPO now stands, also Victoria Square. }\end{array}$ \\
\hline $\begin{array}{l}\text { Mullawirraburka } \\
\text { 'King John' }\end{array}$ & $\begin{array}{l}\text { mulla'dry' + wirra 'forest' + burka 'elder' } \\
\text { More is known about Mullawirraburka than } \\
\text { any other Kaurna person last century. see } \\
\text { Gara (forthcoming). Mullawirraburka had } \\
\text { four wives and his authority was } \\
\text { recognised to some degree by the colonists. }\end{array}$ \\
\hline $\begin{array}{l}\text { Kadlitpinna } \\
\text { 'Captain Jack' }\end{array}$ & Hurtle Square & $\begin{array}{l}\text { kadli'dingo; dog'; + -itpinna 'father of' } \\
\text { Kadlitpinna was also well known to the } \\
\text { colonists. His portrait was painted by } \\
\text { Angas. }\end{array}$ \\
\hline $\begin{array}{l}\text { Ityamaiitpinna } \\
\text { 'King Rodney' }\end{array}$ & Light Square & $\begin{array}{l}\text { ityamaii 'name of student at Piltawodli' } \\
\text {-itpinna 'father of' } \\
\text { Ityamaiitpinna was one of the first Kaurna } \\
\text { to meet the colonists. He was Ivaritji's } \\
\text { father. }\end{array}$ \\
\hline $\begin{array}{l}\text { Ivaritji } \\
\text { Amelia Savage }\end{array}$ & Whitmore Square & $\begin{array}{l}\text { ivaritji 'misty rain' } \\
\text { Ivaritji was most likely the last speaker of } \\
\text { the Kaurna language. She died in 1929. }\end{array}$ \\
\hline Kadnarto Ann Adams & Wellington Square & $\begin{array}{l}\text { Kudnarto 'third born if a female'. Kudnarto } \\
\text { married Tom Adams in 1848 and died in } \\
\text { 1855. She is the ancestor of many Kaurna } \\
\text { people living today. }\end{array}$ \\
\hline
\end{tabular}

*indicates that the term is a neologism (new term) constructed by myself.

$\dagger$ Tarnda Kanya has not been recorded in this form, but has been arrived at through a process of inference and interpretation of sources. The word kanya 'rock' is not actually documented as an independent word in Kaurna sources, though it appears in derivations and certainly exists in related languages such as Adnyamathanha. Numerous quarries were located on the south bank of the Torrens, including where the Railway Station and the Festival Theatre are now located. It is likely that one of these sites was the Tarnda Kanya 'red kangaroo rock'.

\# Victoria Square has since been dual named Tarndanyangga 'red kangaroo rock place'. Tarndanyangga was promoted during the Journey of Healing in 2001 and officially adopted by the Adelaide City Council on 27 May 2002. 


\section{APPENDIX 3}

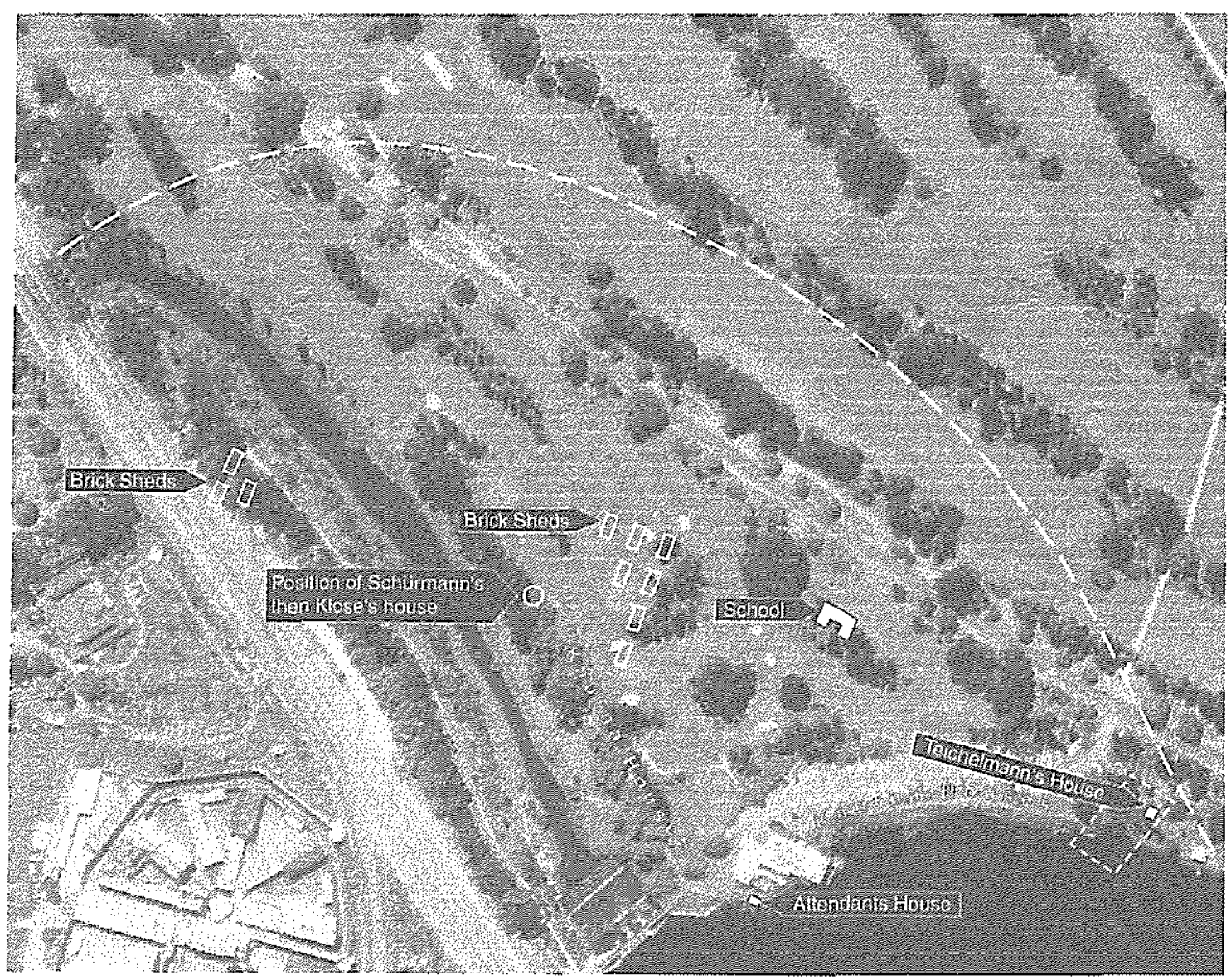

Figure 2: Plaque erected at Piltawodli, May 2000

The text of the Piltawodli plaque is as follows:

Piltawodli (possum home)

This plaque is dedicated to the Kaurna people

Wanti nindo ai kabba kabba? Ningkoandi kuma yerta. ('Where have you pushed me to? You belong to another country.') This Kaurna song was sung by Ngurpo Williamsie in 1844 in protest at the invasion of his country.

In May 1837 the Kaurna people led the 'Protector' of Aborigines to a site across the river to begin the first 'Native Location' in South Australia. In late 1838 it was relocated to this place, known to the Kaurna people as Piltawodli 'possum home'. It included cottages for Kaurna families, cottages for missionaries, gardens, and, by late 1839, a permanent school. In the 1840 s Piltawodli was a fenced area extending over 14 acres.

Piltawodli is especially significant for Kaurna people, because it was here that almost everything we know about the Kaurna language was written down by German missionaries and others. This information was provided by the Kaurna people, particularly Mullawirraburka ('King John'), Kadlitpinna ('Captain Jack') and Ityamaiitpinna ('King Rodney'). The missionaries, Schürmann and Teichelmann, published a grammar and 
vocabulary in 1840 and, along with missionary Klose, taught in the Kaurna language. Each day the children at the school sang or recited hymns, the Ten Commandments, a prayer and some Bible stories. They wrote several letters in Kaurna which still survive. In 1845, the children were relocated to the English-only 'Native School Establishment' on Kintore Avenue and their houses at Piltawodli were destroyed by soldiers.

These children became the first of the 'stolen generations'. On 26 May 2000 many of the descendents of these children returned home to this site.

[Erected by the South Australian 'Bringing Them Home' committee on the second anniversary of National Sorry Day, 26 May 2000.]

Proudly Sponsored by:

Lutheran Church in South Australia

Corporation of the City of Adelaide

\section{REFERENCES}

Amery, Rob, 1996, Kaurna in Tasmania: a case of mistaken identity. Aboriginal History 20:24-50.

— 1998, Warrabarna Kaurna! Reclaiming Aboriginal languages from written historical sources: Kaurna case study. $\mathrm{PhD}$ thesis, University of Adelaide.

- 2000, Warrabarna Kaurna! Reclaiming an Australian language. Lisse, The Netherlands: Swets \& Zeitlinger.

Berndt, Ronald and Catherine Berndt with John Stanton, 1993, A World That Was: the Yaraldi of the Murray River and the Lakes, South Australia. Carlton, Vic.: Melbourne University Press at the Miegunyah Press.

Black, J.M., 1920, Vocabularies of four South Australian languages, Adelaide, Narrunga, Kukata, and Narrinyeri with special reference to their speech sounds. Transactions of the Royal Society of South Australia 44:76-93.

Boynes, Michael, 1992, Submission to Science Park Board of Management for Warriparinga Interpretive Centre prepared by the Marion Environment Team, Marion City Council, October 1992.

Cawthorne, W.A., 1844, Rough notes on the manners and customs of the natives [Archives Department]. Published in Proceedings of the Royal Geographic Society of Australia, SA Branch, Session 1925-26 (1927).

Cockburn, Rodney, 1908, Nomenclature of South Australia. Adelaide: W.K. Thomas \& Co.

— 1990, South Australia. What's in a name? Adelaide: Axiom Publishing (Revised edition. First published in 1984).

Cooper, H.M., 1952, Australian Aboriginal Words and Their Meanings. Second edition, revised and enlarged. (1962, 4th edition). Adelaide: South Australian Museum. 
Cordes, Dean, 1983, The Park at Belair: a social history of the people whose struggles and visions gave South Australia the National Parks and Wildlife Service we cherish today. Vol. 1 . The pioneering decades. Adelaide: the author.

Cotton B.C., ed., 1953, National Parks and Reserves: an account of the national parks and reserves situated near Adelaide, South Australia. Adelaide: Commissioner of the National Park.

Endacott, Sydney J., 1955, Australian Aboriginal Words and Place Names and Their Meanings. Melbourne: Acacia Press (9th enlarged edition).

Foster, Robert, 1990, The Aborigines location in Adelaide: South Australia's first 'mission' to the Aborigines. In Gara, ed., Aboriginal Adelaide, Journal of the Anthropological Society of South Australia 28(1):11-37.

Harris, Rhondda, 1999, Archaeology and post-contact Indigenous Adelaide. Honours thesis, Flinders University, Adelaide.

Hemming, Steve and Rhondda Harris for the Kaurna Aboriginal Community Heritage Committee, 1998, Tarndanyungga Kaurna yerta: A report on the Indigenous cultural significance of the Adelaide parklands. Adelaide Parklands Management Strategy prepared for Hassell Pty Ltd and the Adelaide City Council.

Hughes, Joan, ed., 1989, Australian Words and Their Origins. Melbourne: Oxford University Press.

Ingamells, Rex, 1955, Australian Aboriginal Words: Aboriginal-English, EnglishAboriginal. Melbourne: Hallcroft.

Manning, Geoffrey H., 1986, The Romance of Place Names of South Australia. Adelaide: the author; Gillingham Printers.

Praite, R. and J.C. Tolley, 1970, Place Names of South Australia. Adelaide: Rigby.

Reed, A.W., 1967, Aboriginal Place Names. Sydney: A.H. \& A.W. Reed.

Sugden, Joah H., n.d., Aboriginal Words and Their Meanings. Sydney: Dymock's Book Arcade.

Teichelmann, C.G. and C.W. Schürmann, 1840, Outlines of a Grammar, Vocabulary, and Phraseology, of the Aboriginal Language of South Australia, spoken by the natives in and for some distance around Adelaide. Adelaide: published by the authors at the native location. (Facsimile edition, 1962, State Library of South Australia. Facsimile edition, 1982, Tjintu Books, Adelaide. A copy annotated by Teichelmann was sent to Grey in 1858 and is held in the Sir George Grey Collection, South African Public Library, Cape Town.)

Tindale, Norman B., [Assorted papers] held in the Tindale Collection, Anthropology Section, South Australian Museum, Adelaide.

- Kaurna place names card file held in the Anthropology Section, South Australian Museum, Adelaide.

- 1974, Aboriginal Tribes of Australia: their terrain, environmental controls, distribution, limits and proper names. Berkeley: University of California Press. 
- 1987, The wanderings of Tjirbruki: a tale of the Kaurna people of Adelaide. Records of the South Australian Museum 20:5-13.

Tyrrell, James R., 1933, Australian Aboriginal Place-names and their meanings. Sydney: Simmons.

Webb, Noel Augustin, 1936-37, Place names of the Adelaide Tribe. In Municipal Year Book, City of Adelaide. Printed at The Advertiser, Adelaide, 302-310.

Williams, Georgina and Don Chapman, 1995, The Warriparinga interpretive centre: Aboriginal and non-Aboriginal people working together. In Creating Heritage Partnerships: a selection of papers from the Creating Heritage Partnerships Conference, 21-23 August 1995, 89-98. Canberra: National Museum of Australia.

Williams, William, 1840, The language of the natives of South Australia. The South Australian Colonist 1(19):295-296.

Wyatt, William, 1879, Some account of the manners and superstitions of the Adelaide and Encounter Bay tribes. In J.D. Woods, ed., The Native Tribes of South Australia, 157-181. Adelaide: Government Printer (Original manuscript with corrections in BSL Special Collection). 